\title{
REGULATION OF MIGRATION PROCESSES IN THE TERMS OF GEOPOLITICAL INSTABILITY: LEGAL ISSUES
}

\author{
Anastasiya Prigoda \\ Faculty of Law of the Saint-Petersburg State Economic University, Saint- \\ Petersburg, Russia
}

OMESTE

JEL Category: F22, K37, 015

\begin{abstract}
Over the past decades, the migration processes have undergone an extensive modification, creating the new forms and types of cross-country migration. The problems of migration and the ways of their management in the XXI century became one of the main issues of the developed countries and the subject of acute political debates, they also became an impulse for consolidating the efforts of the Governments in the development of the unified mechanism for the creation a favorable social-economic environment both for migrants and for the inhabitants of the donor countries.
\end{abstract}

In modern conditions, the migration is considered not only from the point of view of the mechanical movement of a population, and, importantly, a special attention is paid to social processes, involving all social-economic climates of the territories. The movement of refugees from the territories covered by ethnic, political and religious contradictions, military conflicts, natural and man-made disasters, generates a lot of problems in the host countries, undermine the existing public order, make adjustments to the lives of local communities, become the cause of the balance changes in the geopolitical map.

All the above mentioned proves the necessity of developing the new approaches to the legal regulation of the international migration policy in the context of achieving a balance between the interests of all participants in migration processes.

Keywords: international law, migration, integration of migrants, multiculturalism, United Nations

\section{INTRODUCTION}

International legal documents regulating the processes of labour migration between countries within integration groupings, as a rule, are liberal in nature. However, there are some problems. Paragraph 52 of the Treaty of Rome signed in 1957, establishing the Common market (ratified in 1968) provides the citizens of the countries - the

Address of the author:

Anastasiya Prigoda

奉= anastasi.prigoda@rambler.ru
EU members, the right to look for work throughout the EU. The Schengen agreement of 1993 established common visa rules. The Dublin Convention of 1990 established rules for granting of asylum. In December 1989, the Charter of fundamental social rights of workers of the EU was adopted. The processes of international labour migration are regulated both by the state and the international legal acts. There are two opposite trends on the basis for the regulation of this process. On the one hand, following the principles of the open economy requires the state to respect the principle of free movement of labour and 
population, and on the other, the real situation in the country forces to apply various prohibitions and restrictions.

\section{METHODOLOGY AND ANALYSES}

A variety of approaches to the problem of immigrants' integration is clearly visible in the examples of France (assimilationist model), Germany (segregation) and the UK (pluralistic model). The first model involves the refusal of immigrants from their old identity and full assimilation of values and behaviours adopted in their new homeland. It is assimilated immigrants who are indistinguishable from the host population, and may be considered as full members of a society. Theoretically, a successful assimilation seems to be beneficial for the national state seeking to preserve a cultural homogeneity, and for an immigrant, because it allows him to fit into a new community.

Thus, during the post-war period, the ethnic groups of immigrants in France have been changed several times. At first, these were mostly individuals of European origin. Then the number of immigrants from the former colonies began to increase (the Maghreb and Tropical Africa). In 1962-1975 the Italians have the highest number of immigrants (32\%), then the Spanish, the Poles, and the Algerians. Since 1975, the most numerous foreign communities became the Portuguese, although it is still lower than the North African (Algeria, Morocco, and Tunisia). The range of countries supplying the immigrants to France is constantly expanding. Dramatically increased the number of immigrants from Asia (especially from the South-East Asia: 1990-1999 by $35 \%$ ), and also Turkey (by $16 \%$ ) and from the Eastern Europe, from Tropical Africa (for the period of 1982-1990 increased by $43 \%$ ). However, the main flow of migrants is now from the Middle East and North Africa, from the countries with unstable political and economic situation, where armed conflicts occur at present.

At the present time, "the leader" by the number of refugees in Europe is Germany. It not only takes more than 40 per cent of all migrants but also unilaterally abandoned the Dublin Agreement, according to which the refugees initially arrived in another country of Europe, cannot submit the immigration documents in Germany. Now those who came to the coasts of Greece and Italy, and then reached Germany, can expect their fate there without worrying about deportation. As a result, in 2015, Germany has already hosted 800 thousand refugees and a total for the entire period of spontaneous migration - more than 1 million 100 thousand. Unlike Germany, the UK, like several other European countries, receives the lowest percentage of refugees and thinks about effective border closures.

In this situation, there are disagreements both of legal and political nature between countries in Europe, which prevent the reasonable compromises and the effective cooperation between the European States in a crisis situation.

International relations, first of all, - is a constructive science. This field of knowledge has never had the relationship with one element of the system, it is multifaceted. The essence of the theory of international relations lies in the description of the life of the state sample on the background of the other, which has a certain relationship, the interaction. It should be noted that it is not excluded the studies of the single nations. To promote the development of international relations and political sociology is possible even just studying and describing quite distant things. When the international system or any of its subsystems is considered as such, there is a subject of international relations theory. Thus, we can say that the relationship between political science and international relations is the same as between psychology and sociology, the transition from a careful study of a single element in certain periods of time to the study of the structure of the interaction between the elements, which characterizes the relation of sciences to each other.

One of the critical problems facing European society, directly related to international relations is the issue of migration. International migration -is not a new phenomenon. In underdeveloped statistics and border system of international migration flows are not particularly carefully recorded by public authorities. The migration process has both positive and negative aspects as for host countries, so for the countries from which people emigrate. Let us examine this problem in more detail. 
For countries the population migrates from, there are more disadvantages, of course than advantages, firstly, with intense emigration the outflow of skilled personnel of the state occurs, and secondly, it is an outflow of taxpayers that deals to a serious hit to the economy, the budget of the country, and the outflow of capital take place. For the host countries, such as Germany, France, Italy, Poland, etc. the influx of working-age population took a negative connotation in most cases. The main feature of migration in Western Europe, according to experts, is the appearance of ethnic enclaves on the territory of the host countries. The researcher I. Tsapenko, for example, notes that it slows down or even stops the assimilation of immigrants and seriously changes the culture and customs of the host cities and countries. Xenophobia and racism there started to gain force, due to the prejudices prevailing in the society and the difficult transition of society from "nation-state" to multiculturalism.

Multiculturalism - is a policy aimed at the development and conservation in a single country and the world in general, cultural differences, and justifying such a policy: theory or ideology. Multiculturalism - is one of the aspects of tolerance, requiring the existence of concurrent cultures for their interpenetration, enrichment, and development in the general human channel of mass culture. The idea of multiculturalism extends mainly in the developed societies of Europe, where there has long been a high level of cultural development. In modern Europe, multiculturalism involves primarily its inclusion in the field of cultural elements of the immigrants' cultures from the countries of the "third world" (including those from the former colonies of European countries). But we should not forget the positive consequences, there had been a decline in the number of unemployed and the impact on social services and infrastructure, the "brain gain", together with trained, innovative thinking migrants, the growth of trade, consumption, the influx of foreign currency and improving the balance of payment.

The question about the refugees' protection should be discussed in a broader context - first, the protection of human rights, and foremost of a refugee in the lights of the Universal Declaration of Human Rights (UN, 1948). There is a special organization that aims to ensure and respect the rights and freedoms of all refugees, regardless of gender, nationality, place of arrival. Office of the United Nations High Commissioner (UNHCR) for Refugees is the main foundation and main protection to disputed situations (UN GA, 1950). For the last 50 years, the management has assisted at least 50 million people in 116 countries around the world. The current policy of the organization is aimed at overcoming the conflict between Western and Eastern Europe, an attempt to avoid clashes between the refugees themselves, to stabilize the influx of refugees, as well as free access to countries, have adopted them. The UN General Assembly and UNHCR have focused on the prevention the exodus of people from the countries of the Middle East, as this action shall be the deprivation of material goods and is a burden for the international community. One of the main reasons for people to leave countries is a violation of the standard fundamental basis of human rights.

The majority of the European countries, during the recent events, have issued new regulations of hosting refugees coming to the countries. The government of Finland on December 8, 2015, has published the new document concerning entrance on the territory of the country of emigrants. According to which, refugees can receive an only temporary residence permit, the issuing of permanent residence permit becomes tougher, two times a year will be undertaken safety assessment in the countries from where the refugees arrive. The refugees can be provided only the most necessary social services. A separate system of social services for new-arrived refugees is being planned. In Germany, on September 13, 2015, the German government established a document, on the basis of which the Schengen area agreement has been suspended, border control faced severe restrictions from the southern borders, and disciplined forces are sent to Bavaria to control the incoming refugees.

Similar measures to provide border security and order have been carried out in a number of countries: Austria, Slovakia, the Czech Republic and Hungary. The policy of tightening border regime is more pronounced, that points to a changing of political course on this aspect. It is worth noting the differing attitudes to this situation, among local, indigenous people of the countries where the rapid flow of refugees and emigrants is 
directed. Changing attitudes of European countries is caused by the emerging panic of the local population and the government in connection with the recent data of refugees' number. In Germany, according to the Vice-Chancellor $\mathrm{H}$. Gabriel, it is already a million arrivals, and not 800 thousand, as reported previously. European politicians have been divided into two groups, the majority demands from the governments, theirs and the neighboring countries, continuing a policy, which is aimed at strengthening the process of hosting refugees. The problem of migration had gone beyond politics; it has become an economic and even a national problem. Serbian Prime Minister, A. Vucic, openly called the German government for cutting the payment of pocket money for the refugees, as these payments are equal to the average salary in Serbia. He also noted that due to such payments, refugees simply will not work, it is not necessary for such amounts. For Europeans, the refugees arriving in their country in a rapid flow are a challenge of national scale. Local people of host countries, as well as politicians, have mixed fillings, but it should be pointed out, that the level of patience and tolerance towards immigrants and refugees fluctuated due to the behavior of the second, disrespect and non-compliance the standard, generally accepted rules of behaviour. The majority of European countries, both of Western and Eastern parts, are keeping the humanity course.

It is worth paying attention to the most important refugees' right - the right not to be subjected to forced return that is expressed in Article 33 of the 1951 Convention (UNTC, 1967) (UNESC, 1966). There are cases when the government of the European countries, in a forced manner, carried out the "return" of refugees to the country they came from, and this is the violation of the people rights and the articles of the Convention as a whole. Very often, the violation generated by the host countries, mainly due to the aggressive behavior of the security forces, can be seen by recourse to article of the Convention "Against Torture and Other Cruel, Inhuman or Degrading Treatment or Punishment" 1984 (UNHR, 1984), due to aggressive behaviour, the use of force, in some cases, of weapons and military equipment, frequently these protection measures from refugees cause physical harm to people or follow by fatal consequences (UNHR, 1984). Some cases of discriminating nature against women migrants, refugees, became world famous, there is the violation of Article of Convention on Human Rights "On the Elimination of All Forms of Discrimination against Women" of 1979 (CEDAW, 1979).

The aid agencies for migrants' assistance are increasing their popularity and importance, they donate food, drinking water, and clothes to those who are between the boundaries of countries, for whatever reason, for example - the closure of the "Balkan route", the area between Macedonia and Serbia. The president of Macedonia George Ivanov has a negative relation to all these events, accusing the countries of Europe, most of all Germany, for the policy they implement towards his country regarding the refugees' question. On March 9, 2016, the authorities of Macedonia after similar decisions of Serbia, Croatia, Slovenia have introduced rigid restrictions for the entrance of migrants. On March 9, 2016, the Macedonian authorities after similar decisions of Serbia, Croatia, and Slovenia had imposed restrictions on immigration. Since 8 March 2016, any migrant has entered Greece, the complete closure of the frontier is reported. The violation of refugees rights is evidently expressed in attempts to find a job in the host country, most people will get a refusal because of their temporary refugee status, but not of shortage of skills, that is another violation of the International Convention "On Protection of the Rights of all Migrant Workers and Members of their Families", which was adopted in 1990 (UN GA, 1990).There are a sufficient number of accidents that has occurred between refugees and the Europeans against the backdrop of religious preferences, basis, and religious ideology. Many European politicians criticize the religious preferences of refugees, thus violating the Declaration "On the Elimination of All Forms of Intolerance and of Discrimination Based on Religion or Belief" adopted in 1981 (A/RES/36/55, 1981)/8/.

\section{CONCLUSIONS}

In view of the above, it gets obviously clear that the problem of refugees is a kind of challenge to the international community, is a test of capacity, whether policy, economic or international legal expertise. Host countries should launch a 
substantial effort to improve their legal system, in order to ensure the rights, freedom and provide full protection to every newcomer, creating patient, tolerant attitude in society towards the representatives of other nations, and the refugees' countries of origin, mandatory, must prevent actions causing a mass migration of citizens. These states must find the underlying causes of such a phenomenon; undertake measures to improve the situation. Of course, one of the most important reasons of emigration processes is a denial of human rights, as mentioned before.

The solution of this problem may be concluded, under the constant supervision of UNHCR and other international legal monitoring bodies, supervising the development process and observing the law in the states problem areas, providing alternative development schemes and the Law regulation covering all aspects of life.

\section{WORKS CITED}

A/RES/36/55. (25 Nov 1981 г.). Members of Their Families. https://www.lawmix.ru/abro/10531. Получено из United Nations: http://www.un.org/documents/ga/res/36/a36r055.htm

CEDAW, U. (1979). Convention on the Elimination of All Forms of Discrimination against Women (CEDAW). Retrieved from UN Women: http://www.un.org/womenwatch/daw/cedaw/

UN. (1948, Dec 10). The Universal Declaration of Human Rights (UDHR). Retrieved from United Nations: http://www.un.org/en/universal-declaration-human-rights/index.html

UN GA. (1950, Dec 14). Ustav upravleniya verkhovnogo komissara organizatsii ob"yedinennykh natsiy po delam bezhentsev. Retrieved from UNHCR: http://reflaw.narod.ru/HTMLs/lows/inter/ustav.htm

UN GA. (1990, Dec 18). International Convention on the Protection of the Rights of All Migrant Workers and Members of Their Families. Retrieved from UNHR: http://www.ohchr.org/EN/Professionallnterest/Pages/CMW.aspx

UNESC. (1966, Nov 18). Protokol, kasayushchiysya statusa bezhentsev. Retrieved from iPolitics: http://www.ipolitics.ru/articles/database/global/protokol_kasaiushiijsia_statusa_bezhentsev_19 66.shtml

UNHR. (1984, Dec 10). Convention Against Torture and Other Cruel, Inhuman or Degrading Treatment or Punishment. Retrieved from United Nations Human Rights: http://www.ohchr.org/EN/Professionallnterest/Pages/CAT.aspx

UNTC. (1967, Jan 31). Protocol Relating to the Status of Refugees. Retrieved from United Nations Treaty Collection: https://treaties.un.org/pages/ViewDetails.aspx?src=TREATY\&mtdsg_no=V$5 \&$ chapter $=5$ \&lang $=$ en

Received for publication: $\quad 12.02 .2016$

Revision received: $\quad 05.04 .2016$

Accepted for publication: $\quad 10.04 .2016$

Kako citirati ovaj rad? / How to cite this article?

Style - APA Sixth Edition:

Prigoda, A. (2016, July 15). Regulation of migration processes in the terms of geopolitical instability: Legal issues. (Z. Čekerevac, Ed.) FBIM Transactions, 4(2), 129-134. doi:10.12709/fbim.04.04.02.13 
Style - Chicago Sixteenth Edition:

Prigoda, Anastasiya. 2016. "Regulation of migration processes in the terms of geopolitical instability: Legal issues." Edited by Zoran Čekerevac. FBIM Transactions (MESTE) 4 (2): 129-134. doi:10.12709/fbim.04.04.02.13.

\section{Style - GOST Name Sort:}

Prigoda Anastasiya Regulation of migration processes in the terms of geopolitical instability: Legal issues [Journal] // FBIM Transactions / ed. Čekerevac Zoran. - Belgrade : MESTE, July 15, 2016. - 2 : Vol. 4. - pp. 129-134.

Style - Harvard Anglia:

Prigoda, A., 2016. Regulation of migration processes in the terms of geopolitical instability: Legal issues. FBIM Transactions, 15 July, 4(2), pp. 129-134.

Style - ISO 690 Numerical Reference:

Regulation of migration processes in the terms of geopolitical instability: Legal issues. Prigoda, Anastasiya. [ed.] Zoran Čekerevac. 2, Belgrade : MESTE, July 15, 2016, FBIM Transactions, Vol. 4, pp. $129-134$ 